\title{
A COMPARISON OF EFECTIVENESS, AND AN ASSESSMENT OF THE QUALITY OF LIFE OF PATIENTS AFTER LAPAROSCOPIC SLEEVE GASTRECTOMY AND ROUX-EN-Y GASTRIC BYPASS
}

\author{
PORÓWNANIE EFEKTYWNOŚCI I OCENA JAKOŚCI ŻYCIA PACJENTÓW \\ PO LAPAROSKOPOWEJ GASTREKTOMII RĘKAWOWEJ I OPERACJI \\ LAPAROSKOPOWEGO OMINIĘCIA ŻOŁĄDKA METODĄ ROUX Y
}

\author{
Oddział Chirurgii Ogólnej i Naczyniowej Specjalistycznego Szpitala im. Prof. Alfreda Sokołowskiego \\ ul. A. Sokołowskiego 11, 70-891 Szczecin \\ Ordynator: dr n. med. Krzysztof Kaseja \\ Zakład Pielęgniarstwa Chirurgicznego i Ratunkowego Wydziału Nauk o Zdrowiu \\ Pomorskiego Uniwersytetu Medycznego w Szczecinie \\ ul. Żołnierska 48, 70-495 Szczecin \\ Kierownik: dr hab. n. med., prof. PUM Włodzimierz Majewski
}

\section{Streszczenie}

Wstęp: Chorobliwa otyłość jest jednym z głównych problemów zdrowotnych w krajach rozwiniętych. Leczenie obejmuje wiele sposobów, jednak najbardziej skuteczne są zabiegi chirurgiczne. Szczególnie przydatne ze względu na minimalną inwazyjność są operacje laparoskopowe.

Celem pracy było porównanie efektywności i jakości życia pacjentów operowanych z powodu chorobliwej otyłości drogą laparoskopowej gastrektomii rękawowej (laparoscopic sleeve gastrectomy - LSG) lub operacji laparoskopowego ominięcia żołądka metodą Roux Y (laparoscopic Roux-en-Y gastric by-pass - LRYGB) wykonanych przez jednego chirurga na jednym oddziale chirurgicznym.

Materiat i metody: W latach 2006-2011 na Oddziale Chirurgii Ogólnej i Naczyniowej Specjalistycznego Szpitala im. Prof. Alfreda Sokołowskiego dwoma metodami operowano 74 pacjentów z chorobliwą otyłością (54 kobiety, 20 mężczyzn). Wykonano zabieg LSG u 33 pacjentów (24 kobiety, 9 mężczyzn) i LRYGB u 41 pacjentów (30 kobiet, 11 mężczyzn). Średni wiek pacjentów w grupach wynosił odpowiednio dla pacjentów operowanych drogą LSG 42,4 lat, a dla operowanych metodą LRYGB - 45 lat. Wskaźnik masy ciała wynosił 46,5 $\pm 8,9 \mathrm{~kg} / \mathrm{m}^{2}$ w grupie LSG i 45,1 $\pm 4,4 \mathrm{~kg} / \mathrm{m}^{2}$ dla grupy LRYGB; wartości były porównywalne. Niezależny obserwator (pielęgniarka operacyjna) oceniał pacjentów w okresie do 6 miesięcy (37 pacjentów) i pomiędzy 7. a 36. miesiącem (37 pacjentów) po zabiegu operacyjnym. Jakość życia pacjentów oceniano za pomocą standaryzowanego kwestionariusza Gastrointestinal Quality of Life Index (GIQLI, wersja polska) wraz z dodatkowymi pytaniami dotyczącymi aktywności seksualnej, fizycznej i innych form aktywności przed zabiegiem operacyjnym oraz po nim.

Wyniki: Nie obserwowano poważniejszych powikłań wczesnych i odległych w obu grupach pacjentów, jednakże jeden pacjent w każdej grupie czuł stały dyskomfort po zabiegu operacyjnym (odpowiednio 2,44\% i 3,03\%). Odsetki utraty nadmiaru wagi w obu grupach były podobne i wynosiły odpowiednio: po 6 miesiącach 38,5\% dla zabiegu LSG oraz 39.9\% dla LRYGB, a po 7-36 miesiącach 64,5\% dla zabiegu LSG oraz 66,9\% dla LRYGB. Ocena jakości życia ujawniła istotnie niższe wartości dla objawów podstawowych po operacji LRYGB w porównaniu do LSG, lecz po LSG nieco częściej występowały zaparcia. Jednakże sumaryczna ocena wartości GIQLI u pacjentów po obu rodzajach zabiegów operacyjnych była porównywalna, a różnica nieistotna statystycznie (110,6 dla zabiegu LSG vs 108,7 dla LRYGB). W obu grupach doszło do istotnej poprawy aktywności seksualnej i aktywności fizycznej po zabiegu operacyjnym. 
Wniosek: Nie stwierdzono istotnych różnic w efektywności i w jakości życia pacjentów po LSG w porównaniu do LRYGB.

H a s $\nmid$ a: chirurgia otyłości - gastrektomia rękawowa - ominięcie żołądka metodą Roux Y - jakość życia efektywność.

\section{Summary}

Introduction: Morbid obesity is nowadays one of the major problems of well developed countries. Treatment of this disease comprises many modalities, but the most successful are surgical ones. With the advent of laparoscopic operations it became clear that these are particularly useful for operation in obese patients due to their minimal invasiveness.

The aim of the study was to compare the effectiveness and quality of life of patients operated on for morbid obesity by laparoscopic sleeve gastrectomy (LSG) and laparoscopic Roux-en-Y gastric by-pass (LRYGB) by one surgeon in one surgical centre.

Material and methods: Between 2006-2011 in the Department of General and Vascular Surgery, Szczecin-Zdunowo Specialist Hospital, 74 morbidly obese patients (54 F, 20 M) were operated on by two methods. Mean age (42.4 and 45 years), and body mass index $\left(46.5 \pm 8.9 \mathrm{~kg} / \mathrm{m}^{2}\right.$ for LSG and $45.1 \pm 4.4 \mathrm{~kg} / \mathrm{m}^{2}$ for LRYGB) respectively, were comparable. One surgeon in one centre performed LSG in 33 patients $(24 \mathrm{~F}, 9 \mathrm{M})$ and LRYGB in 41 patients $(30 \mathrm{~F}$, $11 \mathrm{M})$. An independent observer evaluated patients at times of up to 6 months (37 pts), and after 7 months to 36 months (37 pts) postoperatively. Quality of life was assessed by the Gastrointestinal Quality of Life Index (GIQLI) questionnaire, with accessory questions concerning sexual, physical and other activities before and after intervention.

Results: There were no serious short or long term complications in either group of patients, although one patient in each group felt permanent postoperative discomfort $(2.44 \%$ and $3.03 \%$ ). Percentages of excess weight loss in both groups were similar and reached after 6 months 38.5\% for LSG, $39.9 \%$ for LRYGB, and after 7-36 months $64.5 \%$ for LSG, $66.9 \%$ for LRYGB respectively. Quality of life assessment revealed significantly lower values in core symptoms for patients after LRYGB compared to LSG, but after LSG constipation was slightly more frequent. However, the general GIQLI score for patients after both types of surgery was statistically insignificant (110.6 for LSG versus 108.7 for LRYGB). In both groups sexual and physical activities significantly improved after operation.

Conclusion: There were no significant differences in effectiveness and quality of life in patients after laparoscopic sleeve gastrectomy and laparoscopic Roux-en-Y gastric by-pass.

K ey w o rds: obesity surgery - Roux-en-Y gastric bypass - sleeve gastrectomy - quality of life - effectiveness.

\section{Introduction}

Morbid obesity is nowadays one of the major problems of well developed countries. Treatment of this disease comprises many modalities, but the most successful are surgical ones. With the advent of laparoscopic operations it became clear that these are particularly useful for operation in obese patients due to their minimal invasiveness. Among other operations laparoscopic sleeve gastrectomy (LSG) and laparoscopic Roux-en-Y gastric bypass (LRYGB) seem to be the most promising, offering good excess weight loss (EWL) and low morbidity and mortality $[1,2]$. Although the procedures are widely used, the effectiveness of these operations and the quality of life of patients still requires investigation worldwide.

The aim of the study was to compare the effectiveness and the quality of life of patients operated on for morbid obesity by LSG and LRYGB by the same surgeon in one surgical centre.

\section{Material and methods}

Between 2006 and 2011, in the Department of General and Vascular Surgery, Szczecin-Zdunowo Specialist Hospital, 74 patients $(54 \mathrm{~F}, 20 \mathrm{M})$ who matched the inclusion criteria were operated on by two methods (LSG and LRYGB). Mean patient age was (42.4 and 45 years respectively), and BMI $\left(46.5 \pm 8.9 \mathrm{~kg} / \mathrm{m}^{2}\right.$ for LSG and $45.1 \pm 4.4 \mathrm{~kg} / \mathrm{m}^{2}$ for LRYGB) respectively, were comparable. The same surgeon in one centre performed LSG in 33 patients $(24 \mathrm{~F}, 9 \mathrm{M})$ and LRYGB in 41 patients $(30 \mathrm{~F}, 11 \mathrm{M})$. The LRYGB technique included the formation of a small $(50 \mathrm{cc})$ gastric pouch, a $25 \mathrm{~mm}$ stapler antecolic antegastric side to side gastro-jejunostomy to a $150 \mathrm{~cm}$ antecolic alimentary limb, and an exclusion of $100 \mathrm{~cm}$ of biliopancreatic limb side to side anastomosis. All anastomoses were done by the stapler technique. The LSG was done over a $34 \mathrm{~F}$ bougie beginning approximately 3-4 cm from the pylorus towards the angle of His, by the linear stapler overlap technique. No drains were left in the peritoneal cavity. An independent observer assessed these patients in time intervals up to 6 months ( $37 \mathrm{pts}$ ), and after 7-36 months (37 pts) postoperatively, when patients were investigated and filled out the questionnaire.

\section{Study design}

In this nonrandomized, prospective, parallel group trial, all patients underwent complete evaluation after the respective bariatric operation and during follow-up, including EWL calculations and quality of life assessment. Inclusion criteria comprised: body mass index (BMI) above $35 \mathrm{~kg} / \mathrm{m}^{2}$ with related comorbidity or 40 without comorbidities, age 18-60 years [3]. Exclusion criteria included: BMI above $70 \mathrm{~kg} / \mathrm{m}^{2}$, poorly controlled medical or psychiatric disorders, 
$\mathrm{T}$ a $\mathrm{b}$ l e 1. Baseline demographics of the two groups

\begin{tabular}{|c|c|c|c|c|c|c|c|c|c|c|}
\hline \multirow{2}{*}{ Operation/data } & \multirow{2}{*}{$\begin{array}{c}\text { Number of } \\
\text { patients }\end{array}$} & \multirow{2}{*}{$\begin{array}{l}\text { Mean } \\
\text { age }\end{array}$} & \multirow{2}{*}{ Male } & \multirow{2}{*}{ Female } & \multicolumn{4}{|c|}{ Education } & \multicolumn{2}{|c|}{ Professional activity } \\
\hline & & & & & primary & technical & secondary & high school & yes & no \\
\hline $\begin{array}{l}\text { Laparoscopic } \\
\text { sleeve } \\
\text { gastrectomy }\end{array}$ & $33(44.6 \%)$ & $45 \pm 10.9$ & $9(27 \%)$ & $24(73 \%)$ & $1(3 \%)$ & $7(21 \%)$ & $17(51.5 \%)$ & $8(24 \%)$ & $22(67 \%)$ & $11(33 \%)$ \\
\hline $\begin{array}{l}\text { Laparoscopic } \\
\text { Roux-en-Y } \\
\text { gastric bypass }\end{array}$ & $41(55.4 \%)$ & $42.5 \pm 10$ & $11(27 \%)$ & $30(73 \%)$ & $5(12 \%)$ & $6(15 \%)$ & $14(34 \%)$ & $16(39 \%)$ & $33(80.5 \%)$ & $8(19.5 \%)$ \\
\hline
\end{tabular}

previous major gastrointestinal surgery, active gastrointestinal ulcer or gastro-oesophageal reflux disease, diagnosed or suspected malignancy. Indication for the type of surgical procedure was based on clinical criteria. Ethical committee clearance was obtained from the local review board, and written informed consent was taken from every patient before enrolment.

\section{Effectiveness of the procedure assessment}

This was presented as percentage of EWL at a time up to 6 months and after 7-36 months after the operation. The intended results included percentages of excess weight loss up to $30 \%$ in 6 months and up to $60 \%$ in 12 months [4].

\section{Quality of life assessment}

The Gastrointestinal Quality of Life Index (GIQLI) questionnaire, created in 1994 by Eypasch et al. and then translated into Polish and validated in the year 2005 [5], is used to assess the health-related quality of life of patients with gastrointestinal diseases. The questionnaire comprises 36 items assessing 5 aspects of life: core symptoms, physical items, psychological items, social items, and disease-specific items. Respondents answered every question on a scale: 0-4 ( 0 - worst score, 4 - best score). Total score revealed actual quality of life. The maximum score is 144. Accessory questions concerned demographic data, BMI change, education level, place of residence, professional, sexual and physical activity before and after intervention, sport, alimentary behaviour change, and lifestyle change. Motivation for the bariatric operation was also asked about.

\section{Statistical analyses}

Statistical calculations were made on the MS Excel 2007 and the statistical software package Statistica 7.1 PL. To verify the statistical significance of the answers to the GIQLI questionnaire the U Mann-Whitney test was applied; to assess the statistical significance of other questions Wilcoxon or structural index tests were performed. Values are presented as minimal, maximal, mean and standard deviation value or median with quartiles. A statistical significance
$\mathrm{T}$ a b $1 \mathrm{e} 2$. Preoperative comorbidities in 74 patients

\begin{tabular}{lc}
\multicolumn{1}{c}{ Concomitant diseases } & Number of patients \\
\hline Hypertension & $41(55.4 \%)$ \\
\hline Spine and joint diseases & $31(41.9 \%)$ \\
\hline Diabetes & $21(28.4 \%)$ \\
\hline Heart diseases & $11(14.9 \%)$ \\
\hline Other & $9(39.2 \%)$ \\
\hline No comorbidities & $16(20.3 \%)$ \\
\hline
\end{tabular}

$\mathrm{T}$ a $\mathrm{b}$ l e 3 . Motivations for weight loss surgery in $\mathbf{7 4}$ patients

\begin{tabular}{lc}
\multicolumn{1}{c}{ Motivation } & Number of patients \\
\hline General health deterioration & $58(78.4 \%)$ \\
\hline Comorbidities & $29(39.2 \%)$ \\
\hline Acceptance in society & $27(36.5 \%)$ \\
\hline Sexual problems & $11(14.9 \%)$ \\
\hline Other & $6(8.1 \%)$ \\
\hline
\end{tabular}

was considered at a level of $\mathrm{p}<0.05$. Table 1 provides the baseline demographics of the two groups of patients of the present study.

Regarding place of residence, about half of the patients in both groups lived in towns of up to 100,000 inhabitants 17 (53.5\%) for LSG and 22 (53.6\%) for LRYGB; 8 (25\%) for LSG and 15 (36.6\%) for LRYGB lived in larger towns. Only 7 (22\%) for LSG and 4 (10\%) for LRYGB lived in the countryside. The youngest patient for LSG was 22; the oldest 60 years old. For LRYGB the youngest was 23, the oldest 60 . Table 2 describes co-morbidities in the study groups.

As a major co-morbidity there was hypertension in more than $50 \%$, there were also spine and joint diseases - nearly $42 \%$, diabetes $28 \%$, heart diseases $15 \%$, and others: thyroid problems (3), bronchial asthma (2), depression (1), DVT (1), lower limb oedema (1), varicose veins (1). Twenty percent of patients declared no co-morbidities.

Motivations for weight loss surgery are given in table 3.

In the majority of patients the deterioration of health status was the main motivating factor for bariatric surgery. Co-morbidities, lack of acceptance in society, and sexual problems were also important. Among other reasons given as motivation were: general appearance (1), psychological problems (1), attempt to extend life (1), lack of self-acceptance (1), unsuccessful attempt to lose weight (1), inability to practice their profession (swimming coach -1 ). 
T a b l e 4. Body mass index of patients before the procedure $\left(\mathbf{k g} / \mathbf{m}^{2}\right)$

\begin{tabular}{lcccccc}
\multicolumn{1}{c}{ Operation } & $\begin{array}{c}\text { Number of } \\
\text { patients }\end{array}$ & Min. & Max. & Mean & SD \pm & p \\
\hline Laparoscopic sleeve gastrectomy & 33 & 36.6 & 68 & 46.54 & 8.93 & \\
\hline Laparoscopic Roux-en-Y gastric bypass & 41 & 38.3 & 52.6 & 45.15 & 4.43 & NS \\
\hline All patients & 74 & 36.6 & 68 & 45.76 & 6.8 & \\
\hline
\end{tabular}

$\mathrm{T}$ a b 1 e 5. Excess weight loss in \% in time in both methods

\begin{tabular}{llccccccc}
\multicolumn{1}{c}{ Time from the operation } & $\begin{array}{c}\text { Type of } \\
\text { operation }\end{array}$ & $\begin{array}{c}\text { Number of } \\
\text { patients }\end{array}$ & Min. & Max. & $\begin{array}{c}\text { Lower } \\
\text { quartile }\end{array}$ & Median & $\begin{array}{c}\text { Upper } \\
\text { quartile }\end{array}$ & p \\
\hline $\begin{array}{l}\text { Up to 6 months } \\
(\mathrm{n}=37)\end{array}$ & LSG & 17 & $11.61 \%$ & $92.69 \%$ & $23.51 \%$ & $38.54 \%$ & $51.81 \%$ \\
\hline LRYGB & 20 & $12.04 \%$ & $96.16 \%$ & $24.39 \%$ & $39.99 \%$ & $53.75 \%$ & 0.84 \\
\hline $\begin{array}{l}\text { Between 7-36 months } \\
(\mathrm{n}=37)\end{array}$ & LSG & 16 & $25.82 \%$ & $97.33 \%$ & $51.49 \%$ & $64.45 \%$ & $76.78 \%$ & 0.8 \\
\cline { 2 - 8 }
\end{tabular}

LSG - laparoscopic sleeve gastrectomy, LRYGB - laparoscopic Roux-en-Y gastric bypass

The body mass indexes of patients before the operation are given in table 4 . Both groups were comparable.

\section{Results}

There was no major short or long term complications after both types of operation, although one patient in each group felt permanent postoperative discomfort $(2.44 \%$ and $3.03 \%$ ). Excess weight loss is given in table 5 .

Percentages of excess weight loss after 6 and 7-36 months in both groups were similar and reached 38.5\% for LSG, 39.9\% for LRYGB and 64.5\% for LSG, 66.9\% for LRYGB respectively, but weight between up to 6 months and above 7 to 36 months dropped significantly ( $p<0.001)$. The proportion of patients who achieved EWL greater than $50 \%$ at 7-36 months postoperatively was slightly more than $75 \%$ in both groups. The average percentages of BMI loss in the time of observation up to 36 months postoperatively were also similar and reached $25.1 \%$ for LSG, and $23.8 \%$ for LRYGB (NS). The range of improvement of comorbidities was similar in both groups in the time of observation.

The results of the quality of life questionnaire are given in table 6.

The quality of life assessment revealed significantly lower values in core symptoms in patients after LRYGB compared to LSG (pain, fullness in the epigastrium, flatulence, release of gases, belly bulging, sudden unexpected movement of the intestine, etc.) but in patients after LSG constipation was slightly more frequent. However, general the GIQLI score for patients after both types of surgery was statistically insignificant (110.6 for LSG vs 108.7 for LRYGB).

In both groups sexual and physical activity significantly improved after operation, without differences between groups.

Sexual activity improvement - measured in a scale from 1 (worst possible result) to 10 (best possible result) before the operation (mean $6 \mathrm{SD} \pm 2$ for both methods $\mathrm{p}=0.29$ ) and after the operation (mean $9 \pm 1$ for LSG and mean $8 \pm 1$ for LRYGB, $p=0.087$ ) was comparable in both groups. However, in both groups the improvement before 6 months compared to results after $7-36$ months was significant $(\mathrm{p}<0.001)$.

Physical activity improvement was also reported by the majority of patients - 30 out of 33 (90.9\%) for LSG and 39 out of $41(95.1 \%)$ for LRYGB.

\section{Discussion}

In this nonrandomized prospective study the data of patients operated on by two techniques, LSG and LRYGB, were analyzed in two groups, within observation time of up to 6 months, and 7-36 months postoperatively. Both procedures were performed in one centre by one surgeon with equal experience in both procedures. Data were collected by an independent observer - a registered nurse. According to European Association for Endoscopic Surgery guidelines for bariatric surgery outcome assessment after surgery should include weight loss and maintenance, nutritional status, comorbidities and quality of life. Patients should be seen 3-8 times during the first postoperative year, 1-4 times during the second year, and once or twice a year thereafter [3]. In the present study, in most cases weight loss outcomes did not differ significantly for assessments at up to 6 months, and 7-36 months, nor did comorbidities and quality of life. Excess weight loss within the first year after open sleeve gastrectomy as the sole procedure has been reported to range between $33 \%$ and $45 \%$, and after open LRYGB usually results in $60 \%$ to $70 \%$ according to technical modifications relating to gastric pouch construction, gastro-jejunal anastomosis, and length of alimentary and biliopancreatic limbs. There was no evidence that the laparoscopic approach can change these results [3]. In the present study mean EWL 64.45\% for LSG vs $66.86 \%$ for LRYGB, similar for both methods, fulfils the criterion of the effectiveness of the procedures. 
$\mathrm{T}$ a b 1 e 6. Gastrointestinal quality of life index questionnaire for laparoscopic sleeve gastrectomy compared with laparoscopic Roux-en-Y gastric bypass

\begin{tabular}{|c|c|c|}
\hline Aspects of life & $\begin{array}{l}\text { Laparoscopic } \\
\text { sleeve } \\
\text { gastrectomy }\end{array}$ & $\begin{array}{c}\text { Laparoscopic } \\
\text { Roux-en-Y } \\
\text { gastric bypass }\end{array}$ \\
\hline \multicolumn{3}{|c|}{ Core symptoms $(\mathrm{p}=0.04)^{*}$} \\
\hline Pain & $3.27 \pm 0.84$ & $3.19 \pm 0.81$ \\
\hline Bloating & $3.30 \pm 0.73$ & $3.05 \pm 1.05$ \\
\hline Epigastric fullness & $2.91 \pm 0.80$ & $2.51 \pm 1.03$ \\
\hline Flatus & $2.70 \pm 0.88$ & $2.32 \pm 1.08$ \\
\hline Belching & $2.97 \pm 0.81$ & $2.78 \pm 1.08$ \\
\hline Bowel frequency & $3.58 \pm 0.66$ & $3.14 \pm 0.96$ \\
\hline Abdominal noises & $3.27 \pm 0.84$ & $2.41 \pm 1.07$ \\
\hline Restricted eating & $2.12 \pm 1.22$ & $2.27 \pm 1.20$ \\
\hline Enjoyment with eating & $2.85 \pm 0.91$ & $2.83 \pm 1.09$ \\
\hline Fatigue & $2.45 \pm 0.90$ & $2.37 \pm 0.86$ \\
\hline \multicolumn{3}{|c|}{ Physical items $(\mathrm{p}=0.66)$} \\
\hline Strength loss & $2.79 \pm 1.17$ & $2.88 \pm 1.23$ \\
\hline Feeling unwell & $2.61 \pm 0.90$ & $2.76 \pm 0.73$ \\
\hline Feeling unfit & $2.70 \pm 1.10$ & $2.80 \pm 1.10$ \\
\hline Endurance loss & $2.91 \pm 1.28$ & $3.00 \pm 1.24$ \\
\hline Waking up at night & $3.21 \pm 0.99$ & $2.54 \pm 1.42$ \\
\hline Appearance & $2.94 \pm 0.97$ & $2.71 \pm 1.17$ \\
\hline \multicolumn{3}{|c|}{ Psychological items $(\mathrm{p}=0.66)$} \\
\hline Sadness & $2.85 \pm 1.00$ & $2.88 \pm 1.10$ \\
\hline Nervousness & $2.73 \pm 0.98$ & $2.88 \pm 0.98$ \\
\hline Frustration & $3.00 \pm 1.06$ & $3.02 \pm 0.88$ \\
\hline Happiness & $2.85 \pm 0.76$ & $2.85 \pm 0.96$ \\
\hline Bothered by treatment & $3.39 \pm 1.09$ & $3.54 \pm 0.78$ \\
\hline Coping with stress & $2.97 \pm 0.88$ & $3.02 \pm 1.01$ \\
\hline \multicolumn{3}{|c|}{ Social items $(p=0.73)$} \\
\hline Daily activities & $3.21 \pm 1.19$ & $3.41 \pm 0.77$ \\
\hline Leisure activities & $3.15 \pm 1.09$ & $3.24 \pm 0.86$ \\
\hline Sexual life & $3.55 \pm 0.90$ & $3.39 \pm 1.14$ \\
\hline Personal relations & $3.61 \pm 1.09$ & $3.61 \pm 0.80$ \\
\hline \multicolumn{3}{|c|}{ Disease-specific items $(\mathrm{p}=0.99)$} \\
\hline Regurgitation & $3.06 \pm 0.97$ & $3.20 \pm 0.84$ \\
\hline Dysphagia & $3.30 \pm 1.05$ & $3.37 \pm 0.86$ \\
\hline Eating speed & $2.85 \pm 1.15$ & $2.93 \pm 1.17$ \\
\hline Nausea & $2.97 \pm 1.07$ & $3.05 \pm 0.89$ \\
\hline Diarrhoea & $3.55 \pm 0.90$ & $3.15 \pm 1.01$ \\
\hline Bowel urgency & $3.45 \pm 0.75$ & $3.17 \pm 0.86$ \\
\hline Constipation & $2.64 \pm 1.19$ & $3.07 \pm 1.06$ \\
\hline Blood in stool & $3.73 \pm 0.84$ & $3.88 \pm 0.40$ \\
\hline Heartburn & $3.39 \pm 1.03$ & $3.76 \pm 0.70$ \\
\hline Uncontrolled stools & $3.79 \pm 0.65$ & $3.68 \pm 0.65$ \\
\hline Total score $(p=0.56)$ & $110.61 \pm 34.66$ & $108.66 \pm 34.87$ \\
\hline
\end{tabular}

* Comparison of aspects of life in both groups

Laparoscopic Roux-en-Y gastric bypass is presently the gold standard, resulting in greater weight loss than purely restrictive procedures; LSG is a novel bariatric procedure that avoids intestinal bypass [6]. Among other bariatric interventions LSG has been recently identified as an independent effective operation [7]. Formerly it was considered a part of other more complicated interventions like duodenal switch $[1,8,9]$. The weight loss after this intervention is not only due to the reduction of gastric capacity, but also to the removal of gastric fundus, a site of production of ghreline - a hypothetical hormone of appetite $[6,10,11]$. Furthermore, performing this procedure does not exclude reoperation and applying other bariatric techniques if EWL is not considered adequate $[2,6]$. Similarly to our findings, others present no significant difference in the effectiveness of LSG in comparison with LRYGB in EWL at the same time of observation $[6,12,13,14]$. Furthermore, both procedures achieve equivalent improvement in glycemic control over a 1-year follow-up period $[6,10,12]$. The improvement of lipid profile after LSG is only slightly worse than after LRYGB [12]. At 30-day analysis LSG is associated with a shorter operating time and fewer early minor complications compared to LRYGB. There are no significant differences in major complications or early reoperations [15]. This study, assessing patients at a time of up to 6 and from 7-36 months after the operation presenting the results during the process of weight loss, confirms the high effectiveness of both procedures, although it does not show any significant differences in both methods regarding excess weight loss and the quality of life of patients. However, others in longer term follow-up show significantly better EWL in patients after LRYGB in 2 years, equalizing after 3 years of investigation [16]. The mortality and morbidity rates and hospital stay for both LSG and LRYGB procedures are significantly lower than, e.g. for biliopancreatic diversion, which can force bariatric surgeons to chose these techniques [15]. The risk of leak after LSG, although small (2.4\%), found usually at the proximal third of the stomach, is mostly diagnosed after discharge from the hospital [16]. However, one can not recommend one primary procedure over another as each procedure poses different risks and benefits. The chosen surgical method should be based on specific patient goals and motivations, and the surgeon's and institution's expertise and experience. Laparoscopic procedures are now preferred over open ones due to lower early postoperative morbidity and mortality [17].

The GIQLI questionnaire is capable of providing information on generic as well as on specific aspects of digestive symptoms and quality of life. For this reason, GIQLI has been extensively used in different pathologies and to evaluate medical treatments or surgical procedures performed on the digestive tract [18]. There are other questionnaires available, some of them made for bariatric purposes [19, 20,21], but currently most authors chose the GIQLI questionnaire, maybe because of good correlation between the degree of obesity (BMI) and the alteration of the GIQLI global and subscales scores [22]. Thus, the questionnaire was chosen for the present study. Quality of life deterioration, a frequent motivation for bariatric surgery, increasing after the procedure to the nearly normal range does not favour any operative technique in this study. Taking into account that the score of quality of life of obese patients without operation reported by other sources at a range of 95 points, and the score for healthy populations of similar age reaches 122 points [23] values 110.6 for LSG and 108.7 for LRYGB, 
indicate substantial improvement of QOL. Some other studies investigating quality of life after both operations share this opinion $[23,24]$.

Sexual life and physical activity also substantially improve in both groups, which seems obvious with weight loss.

\section{Conclusion}

In observation time up to 36 months after the procedure there is no difference in the effectiveness of laparoscopic sleeve gastrectomy and laparoscopic Roux-en-Y gastric bypass in terms of weight loss and quality of life. Both procedures significantly improve the total GIQLI score to a similar extent. However, these results require confirmation in larger groups of patients in randomized studies.

\section{References}

1. Stanowski K., Paśnik K.: Bariatric surgery - the current state of knowledge. Wideochir Tech Małoinwaz. 2008, 3, 2, 71-86.

2. Szewczyk T., Janczak P., Duszewski M., Modzelewski B.: Technical problems in laparoscopic sleeve gastrectomy. Wideochir Tech Małoinwaz. 2009, 4, 3, 95-101.

3. Sauerland S., Angrisani L., Belachev M., Chevallier J.M., Favretti F., Finer N. et al:: Obesity surgery: evidence based guidelines of the European Association for Endoscopic Surgery (EAES). Surg Endosc. 2005, 19, 2, 200-221.

4. Buchwald H., Avidor Y., Braunwald E., Jensen M.D., Pories W., Fahrbach K. et al:: Bariatric surgery: a systematic review and meta-analysis. JAMA. 2004, 292, 1724-1737.

5. Majewski W.D.: Long-term outcome, adhesions, and quality of life after laparoscopic and open surgical therapies for acute abdomen: follow-up of a prospective trial. Surg Endosc. 2005, 19, 1, 81-90.

6. Peterli R., Steinert R.E., Woelnerhanssen B., Peters T., Christoffel-Courtin K., Gass M. et al.: Metabolic and hormonal changes after laparoscopic Roux-en-Y gastric bypass and sleeve gastrectomy: a randomized, prospective trial. Obes Surg. 2012, 22, 5, 740-748.

7. Chopra A., Chao E., Etkin Y., Merklinger L., Lieb J., Delany H.: Laparoscopic sleeve gastrectomy for obesity: can it be considered a definitive procedure? Surg Endosc. 2012, 26, 3, 831-837.

8. Praveen Raj P., Kumaravel R., Chandramaliteeswaran C., Rajpandian S., Palanivelu $C$.: Is laparoscopic duodenojejunal bypass with sleeve an effective alternative to Roux en Y gastric bypass in morbidly obese patients: preliminary results of a randomized trial. Obes Surg. 2012, 22, 3, 422-426.

9. Trybull A., Frask A., Michalik M.: Sleeve gastrectomy. Wideochir Tech Małoinwaz. 2008, 3, 4, 205-209.

10. Ramón J.M., Salvans S., Crous X., Puig S., Goday A., Benaiges D. et al.: Effect of Roux-en-Y gastric bypass vs sleeve gastrectomy on glucose and gut hormones: a prospective randomised trial. J Gastrointest Surg. $2012,16,6,1116-1122$.
11. Lee W.J., Chen C.Y., Chong K., Lee Y.C., Chen S.C., Lee S.D.: Changes in postprandial gut hormones after metabolic surgery: a comparison of gastric bypass and sleeve gastrectomy. Surg Obes Relat Dis. 2011, 7, 6, 683-690.

12. Nocca D., Guillaume F., Noel P., Picot M.C., Aggarwal R., El Kamel M. et al.: Impact of laparoscopic sleeve gastrectomy and laparoscopic gastric bypass on HbAlc blood level and pharmacological treatment of type 2 diabetes mellitus in severe or morbidly obese patients. Results of a multicenter prospective study at 1 year. Obes Surg. 2011, 21, 6, 738-743.

13. Bayham B.E., Greenway F.L., Bellanger D.E., O'Neil C.E.: Early resolution of type 2 diabetes seen after Roux-en-Y gastric bypass and vertical sleeve gastrectomy. Diabetes Technol Ther. 2012, 14, 1, 30-34.

14. Benaiges D., Flores-Le-Roux J.A., Pedro-Botet J., Ramon J.M., Parri A., Villatoro M. et al.: On behalf the Obemar Group (2012) Impact of Restrictive (Sleeve Gastrectomy) vs Hybrid Bariatric Surgery (Roux-en-Y Gastric Bypass) on Lipid Profile. Obes Surg. 2012, 22, 8, 1268-1275.

15. Helmiö M., Victorzon M., Ovaska J., Leivonen M., Juuti A., Jaser N. et al.: Sleevepass: A randomized prospective multicenter study comparing laparoscopic sleeve gastrectomy and gastric bypass in the treatment of morbid obesity: preliminary results. Surg Endosc. 2012, 26, 9, 2521-2526.

16. Boza C., Gamboa C., Salinas J., Achurra P., Vega A., Pérez G.: Laparoscopic Roux-en-Y gastric bypass versus laparoscopic sleeve gastrectomy: a case-control study and 3 years of follow-up. Surg Obes Relat Dis. 2012, 8, 3, 243-249.

17. Paluszkiewicz R., Kalinowski P., Wróblewski T., Bartoszewicz Z., Białobrzeska-Paluszkiewicz J., Ziarkiewicz-Wróblewska B. et al.: Prospective randomized clinical trial of laparoscopic sleeve gastrectomy versus open Roux-en-Y gastric bypass for the management of patients with morbid obesity. Videosurgery Miniinv. 2012, 7, 4, 225-232.

18. de la Matta-Martín M., Acosta-Martínez J., Morales-Conde S., Herrera-González A.: Perioperative morbi-mortality associated with bariatric surgery: from systematic biliopancreatic diversion to a tailored laparoscopic gastric bypass or sleeve gastrectomy approach. Obes Surg. 2012, 22, 7, 1001-1007.

19. Aurora A.R., Khaitan L., Saber A.A.: Sleeve gastrectomy and the risk of leak: a systematic analysis of 4,888 patients. Surg Endosc. 2012, 26, 6, 1509-1515.

20. Poves Prim I., Macias G.J., Cabrera Fraga M., Situ L., Ballesta López C.: Quality of life in morbid obesity. Rev Esp Enferm Dig. 2005, 97, 3, 187-195.

21. Suter M., Calmes J.M., Paroz A., Giusti V.: A new questionnaire for quick assessment of food tolerance after bariatric surgery. Obes Surg. 2007, 17, 1, 2-8.

22. Weiner S., Sauerland S., Weiner R., Cyzewski M., Brandt J., Neugebauer E.: Validation of the adapted Bariatric Quality of Life Index $(\mathrm{BQL})$ in a prospective study in 446 bariatric patients as one-factor model. Obes Facts. 2009, 2, Suppl 1, 63-66.

23. Poghosyan T., Polliand C., Bernard K., Rizk N., Valensi P., Champault $G$.: Comparison of quality of life in morbidly obese patients and healthy volunteers. A prospective study using the GIQLI questionnaire. J Chir (Paris). 2007, 144, 2, 129-133.

24. Overs S.E., Freeman R.A., Zarshenas N., Walton K.L., Jorgensen J.O.: Food tolerance and gastrointestinal quality of life following three bariatric procedures: adjustable gastric banding, Roux-en-Y gastric bypass, and sleeve gastrectomy. Obes Surg. 2012, 22, 4, 536-543. 